\title{
International Law and State Behavior: Commitment and Compliance in International Monetary Affairs
}

\section{Citation}

Simmons, Beth A. 2000. International law and state behavior: commitment and compliance in international monetary affairs. American Political Science Review 94, no. 4: 819-835.

\section{Published Version}

http://dx.doi.org/10.2307/2586210

\section{Permanent link}

http://nrs.harvard.edu/urn-3:HUL.InstRepos:3153320

\section{Terms of Use}

This article was downloaded from Harvard University's DASH repository, and is made available under the terms and conditions applicable to Other Posted Material, as set forth at http:// nrs.harvard.edu/urn-3:HUL.InstRepos:dash.current.terms-of-use\#LAA

\section{Share Your Story}

The Harvard community has made this article openly available.

Please share how this access benefits you. Submit a story.

Accessibility 


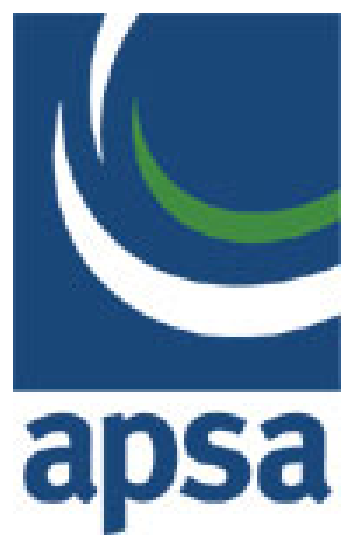

International Law and State Behavior: Commitment and Compliance in International Monetary Affairs

Author(s): Beth A. Simmons

Source: The American Political Science Review, Vol. 94, No. 4 (Dec., 2000), pp. 819-835

Published by: American Political Science Association

Stable URL: http://www.jstor.org/stable/2586210

Accessed: 21/05/2009 10:06

Your use of the JSTOR archive indicates your acceptance of JSTOR's Terms and Conditions of Use, available at http://www.jstor.org/page/info/about/policies/terms.jsp. JSTOR's Terms and Conditions of Use provides, in part, that unless you have obtained prior permission, you may not download an entire issue of a journal or multiple copies of articles, and you may use content in the JSTOR archive only for your personal, non-commercial use.

Please contact the publisher regarding any further use of this work. Publisher contact information may be obtained at http://www.jstor.org/action/showPublisher?publisherCode=apsa.

Each copy of any part of a JSTOR transmission must contain the same copyright notice that appears on the screen or printed page of such transmission.

JSTOR is a not-for-profit organization founded in 1995 to build trusted digital archives for scholarship. We work with the scholarly community to preserve their work and the materials they rely upon, and to build a common research platform that promotes the discovery and use of these resources. For more information about JSTOR, please contact support@ jstor.org. 


\title{
International Law and State Behavior: Commitment and Compliance in International Monetary Affairs BETH A. SIMMONS University of California, Berkeley
}

\begin{abstract}
$W$ hy do sovereign governments make international legal commitments, and what effect does international law have on state behavior? Very little empirical research tries to answer these questions in a systematic way. This article examines patterns of commitment to and compliance with international monetary law. I consider the signal governments try to send by committing themselves through international legal commitments, and I argue that reputational concerns explain patterns of compliance. One of the most important findings is that governments commit to and comply with legal obligations if other countries in their region do so. Competitive market forces, rather than overt policy pressure from the International Monetary Fund, are the most likely "enforcement" mechanism. Legal commitment has an extremely positive effect on governments that have recently removed restrictive policies, which indicates a desire to reestablish a reputation for compliance.
\end{abstract}

I nternational relations has long been concerned with the role of rules in the organization of international political life. Why do governments commit themselves to international rules, and under what conditions do they comply with their commitments? This is a pioneering area of research for international relations and legal scholars alike (Burley 1993; Chayes and Chayes 1995; Downs, Rocke, and Barsoom 1996; Weiss and Jacobson 1998; Young 1979). What is at stake is whether and to what extent sovereign behavior can be influenced by a legal commitment to rules of conduct. This question, in turn, is at the root of major disagreements between realist and institutionalist theorists in international relations (see Keohane and Martin 1995; Mearsheimer 1994-95).

The literature on international rule compliance is quite disparate in methods, theoretical orientation, and findings. Early quantitative work suggested that much international behavior is consistent with international law, even in the conduct of hostilities between states (Kegley and Raymond 1981; Tillema and Van Wingen 1982). It has been far more difficult to show a convincing causal link between legal commitments and behavior, however. Some progress has been made in the examination of compliance with environmental agreements; in-depth case studies have demonstrated that technical "capacity" is a necessary although not sufficient condition to secure compliance with agreements that require technical policy implementation. Weiss and Jacobson (1998) compare the performance of nine countries with respect to five environmental accords and conclude, among other things, that administrative and technical capacities (including knowledge and training, adequate authority and financial resources,

Beth A. Simmons is Associate Professor of Political Science, University of California, Berkeley, CA 94720-1950 (bsimmons@ socrates.berkeley.edu).

The author thanks Henry Brady, William Clark, Robert Keohane, Barbara Koremenos, Brian Pollins, and Eric Schickler for very helpful comments. I also acknowledge the extremely helpful research assistance of Zachary Elkins and Conor O'Dwyer, who assisted with data management and analysis; Becky Curry, who assisted with the legal research; and Aaron Staines and Jennie Wang, who assisted with research and data entry. All errors remain my own. and access to relevant information) are crucial to compliance (see also Haas, Keohane, and Levy 1993). These arguments are less telling, however, where governments are obligated to refrain from particular activities rather than implement complex technical accords.

Others argue that the domestic regime type is essential to understanding international law compliance (Slaughter 1995). Governments based on the rule of law and, especially, the independence of the judicial branch are, in this view, much more likely to comply with international obligations than those that are not. Liberal democracies are likely to commit to rules that reflect their ideological biases and to comply with them. This proposition has not been put to a rigorous test, but it seems to dovetail with the strand of the democratic peace literature that argues regard for domestic constitutional constraints carries over into the conduct of foreign policy (Dixon 1993; RisseKappen 1995).

The most serious challenge to any of these studies is that they are not able to show credibly that compliance is based on anything other than immediate state or governmental interests. This leaves most studies on compliance subject to the criticism that rules add little to our understanding of international relations: They reflect rather than alter governments' interest in pursuing a particular course of action (Downs and Rocke 1995; Mearsheimer 1994-95).

My argument is that international legal rules do alter governments' interests in compliant behavior. International legal commitment is a bid to make a credible commitment to a particular policy stance. The acceptance of treaty obligations raises expectations about behavior that, once made, are reputationally costly for governments to violate. An international legal commitment is one way that governments seek to raise the reputational costs of reneging, with important consequences for state behavior. I demonstrate this effect in the context of the public international law of money, an area in which governments traditionally have guarded jealously their sovereign decision-making status (Cohen 1998). In 1945, for the first time in history a treaty regime was established governing money and the inter- 
national payments system, to be administered by the International Monetary Fund (IMF). This agreement required adherents to keep their current account free from restriction. Put most simply, if a bill comes due for imports or for an external interest payment, national monetary authorities should make foreign exchange available to pay it. This obligation is assumed voluntarily, but once made it is legally binding and permanent. The IMF Articles of Agreement provide an opportunity to test whether a rule influences behavior, even when governments face unanticipated circumstances that make compliance inconvenient or even costly in the short run.

The first section provides an overview of the substantive monetary rules under consideration and formulates expectations for commitment and compliance. The second section presents data to address three questions. Why do governments commit themselves to these rules? Under what conditions do they comply? Does commitment to an international rule affect government behavior? The final section explores the findings, provides interpretations, and draws conclusions.

The evidence suggests that legal commitments are crucial to policy choice. Taken as a whole, the findings are most consistent with an interpretation that governments make commitments to further their interests and comply with them to preserve their reputation for predictable behavior in the protection of property rights. Strong regional effects suggest that reputations develop around regional standards of behavior. A positive reputation for respecting the rule of law domestically is associated with compliance, which suggests that whenever possible governments will avoid damaging a valuable reputation for law-governed behavior; this consideration deters them from breaking the law in the international sphere. The influence of a formal legal obligation is especially strong in the first few years after a period of restrictions, which is consistent with the desire of legally committed countries to reestablish their credibility for openness. The implication is that despite the formal ability of the IMF to enforce the rules, it is likely to be the market that "enforces" the public international law of money. The broader message for theorists of international relations is that enforcement need not be overt and centralized to give behavioral rules their bite.

\section{MARKETS AND INTERNATIONAL MONETARY LAW: EXPECTATIONS REGARDING COMMITMENT AND COMPLIANCE}

The IMF's Articles of Agreement are the first international accord in history to obligate signatories to particular standards of monetary conduct. Article VIII spells out the general obligations of members, and Section 2 rules prohibit restrictions on the making of payments and transfers for current international transactions. ${ }^{1}$ The purpose is to do what international trade

\footnotetext{
1 Current transactions include payment for goods, services, and "invisibles"-insurance charges, warehousing charges, shipping,
}

law had been doing for decades: provide a framework that facilitates the exchange of goods, services, and capital among countries. ${ }^{2}$

Governments may not wish to maintain an open current account for two main reasons. One may be to support developmental objectives that favor certain kinds of transactions (exports, capital inflows) over others (imports, capital outflows) based on established state priorities. The other may be to ameliorate balance-of-payments problems (Edwards 1985, 381-2). Under these conditions, governments usually want to retain the flexibility of intervening to conserve foreign exchange in whatever ways they consider appropriate.

The IMF has always viewed such systems of control as dangerous substitutes for economic adjustment and as inhibitors to the development of free foreign exchange markets. But because many of the IMF's founding members could not immediately achieve full convertibility, Article VIII obligations are voluntarily. Upon joining the fund, new members can avail themselves of transitional arrangements under Article XIV, which effectively grandfather restrictions in place upon their accession. ${ }^{3}$ Yet, the articles do not specify either a time limit on the transitional period or a set of criteria for ending it (De Vries and Horsefield 1969, 225). The IMF encourages countries it believes are in a position to do so to make an Article VIII commitment, but there are no direct positive or negative incentives.

Furthermore, the IMF does not directly enforce obligations, although it publishes data on states' policies from which one can infer compliance (see the Appendix). The Executive Board can approve restrictions (or not), and this role may be quite important in ensuring a degree of transparency in distinguishing policies consistent with a contingent rule from the exercise of sheer policy discretion. Technically, the Executive Board can declare a member ineligible to use the resources of the fund if it "fails to fulfill any of its obligations" under the articles, ${ }^{4}$ and noncompliance sometimes interrupts drawings under stand-by and extended arrangements. 5 The IMF has used these formal remedies very sparingly. Noncompliers rarely

business and tourist travel, family remittances, royalties, dividends interest, and other noncapital transactions. The articles explicitly permit the regulation of international capital movements (Article VI, section 3).

${ }^{2}$ Article IV, section 1. The original White Plan advocated "the general policy of foreign exchange trading in open, free and legal markets, and the abandonment as rapidly as conditions permit of restrictions on exchange controls" (Horsefield and deVries 1969, 64). ${ }^{3}$ Article XIV, section 2. An Article XIV country also can adapt its restrictions without the need for IMF approval, but it cannot introduce new restrictions without approval; cannot adapt multiple currency practices without approval; and cannot maintain restrictions that the member cannot justify as necessary for balance-ofpayments reasons (see Horsefield 1969, 248-59).

4 Article XV, section 2(a).

5 According to Gold $(1988,466)$ : “All standby arrangements include a uniform term on measures that directly or indirectly affect exchange rates. Under this term a member is precluded from making purchases under an arrangement if at any time during the period of the arrangement the member: '(i) imposes [or intensifies] restrictions on payments and transfers for current international transactions; or (ii) introduces [or modifies] multiple currency practices; or (iii) concludes bilateral payments agreements which are inconsistent with 
have to worry about direct retaliation, since members that vote for some kind of punishment may be concerned about similar treatment in the future. The fund is much more likely to try persuasion than apply a remedy for continued noncompliance (Gold 1979, 185).

My analysis focuses on enforcement that flows from market rather than official sources (Greif 1992, 1993; Greif, Milgrom, and Weingast 1994; Milgrom, North, and Weingast 1990). The literature on time-inconsistent policy stresses private actors' broadly held belief that a government's optimal ex post policy may differ from its optimal ex ante strategy (Barro and Gordon 1983; Canzoneri and Henderson 1991; Kydland and Prescott 1977; Staigler and Tabellini 1987). In the case of time-inconsistent policies with fixed preferences, it is difficult for a government to commit to refrain from altering policy in the future. Alternatively, one can understand a commitment to Article VIII as an attempt by governments to signal their future policy stance under conditions of incomplete information. In this case, resolving the credibility problem requires the government to be able to signal its "true type." Of course, such a signal is only meaningful if it helps private actors separate true liberalizers from governments that are more committed to other goals, such as redistribution. The key is for the true reformer to be able to send a signal that distinguishes it from a less committed type (Persson 1988; Persson and Tabellini 1989; Spence 1974). Rodrik (1989) emphasizes that in order to send a credible signal of true intentions in an incomplete information environment, a government may have to send a stronger signal than it would in the absence of a credibility problem.

My argument is that Article VIII commitment is one way in which governments may seek to enhance their credibility to markets that doubt their ability or willingness to maintain current account policy liberalization into the future. Governments that are interested in efficiency gains from international transactions have good reasons to establish their credibility through such a commitment. True, there are alternative mechanisms (Rowlands 1993), but few provide as clear a signal or as potentially binding a constraint as an Article VIII commitment. For governments whose credibility suffers from a basic problem of time inconsistency, Article VIII triggers more stringent scrutiny than would be the case with a simple policy pronouncement.

Whatever the source of government credibility, Article VIII raises the costs of policy reversal in three ways. (1) It focuses expectations on a clear codified standard, the exact meaning of which has been authoritatively interpreted by the Executive Board of the IMF. (2) It provides transparency through regular consultations with the fund staff. (3) It mobilizes a new set of external actors (private economic, governmental, and legal) who may exert pressure to comply on a government that is considering or engaging in rule violation. Indeed, as Lipson (1991) argues, treaties are

Article VIII; or (iv) imposes [or intensifies] import restrictions for balance of payments reasons.'", designed, by long-standing convention, to raise the credibility of promises by staking national reputation on adherence to them (see also Abbott and Snidal 2000). The potential for incurring costs can be very helpful in making a credible commitment in the first place (Martin 1993).

This is not to suggest that Article VIII is a straightjacket on governmental policy choice, but few international commitments are. In a time-inconsistency framework, contingent rules allow for temporary departures under well-understood circumstances (Bordo and Kydland 1995; Bordo and Rockoff 1996). Recent innovations in signaling models explore the conditions under which reneging on a pledge need not harm reputation: If it occurs under circumstances that are known to be especially adverse, then this action will not reveal how a particular government will behave in more normal times. Rule violation, in extreme cases, is therefore not informative for purposes of developing a reputation (Drazen 1997). Review by the IMF Executive Board regarding temporary approval of restrictions that violate Article VIII obligations provides the flexibility recently incorporated into reputational models.

The literature gives relatively little attention to the problem of establishing credibility in an international setting when there is competition among jurisdictions. An emerging empirical stream suggests, however, that countries with poor protection for investors, measured by both the character of legal rules and the quality of law enforcement, tend to have small and narrow capital markets (La Porta et al. 1997) as well as more limited and costly access to the pool of international capital (Sobel 1999). Studies also have established the link between corruption and other national risks and trends in foreign investment (Ramcharran 1999; Wei 2000). Investors and traders can choose among a range of business venues, and they prefer to do business in venues characterized by a national commitment to the protection of property rights. Therefore, governments compete for international business through various reputational devices (see, e.g., Maxfield 1997) in the same way that they are forced to compete in a broad range of regulatory areas when factors of production are mobile (Aman 1995; Cerny 1994; Oberhansli 1997; Sinn 1999; Tiebout 1956).

The first expectation is policy convergence, especially among countries whose venues are near substitutes for one another. Governments that lag significantly the policies of their more credibly liberal competitors place their business sector at a competitive disadvantage. Yet, economic agents are likely to tolerate noncompliance if it is rampant among similar states. There are two reasons for this, and both relate to the consequences of noncompliance. First, to renege when everyone else does is likely to be interpreted as a situation sufficiently dire to justify the contingency of the rule. In a signaling framework, noncompliance in the context of generalized violation may not provide clear information on a country's future policy intentions. Second, investors and traders incur high costs (and run into collective action problems) if they attempt to punish numerous violators. Noncompliance is 
much less costly for a particular government if many others are also in violation. Thus, the decision to liberalize the foreign exchange market is strongly influenced by the policies adopted by international competitors.

The second expectation is that a reputation for the rule of law correlates with compliance. One implication of viewing market pressures as the primary enforcement mechanism for international monetary rules is that a government should be very concerned to develop a reputation for openness and especially predictability. Moreover, governments that have invested in and rest on a stable legal framework at home are unlikely to jeopardize this reputation by lightly flouting international legal obligations. Governments that regularly ignore property rights do not have much reputation to lose. Similarly, after a period of noncompliance, governments committed to Article VIII have an incentive to reestablish their credibility swiftly by returning to predictable, open behavior as soon and as convincingly as possible. In short, a public legal commitment to the international community raises expectations and encourages compliance, even under difficult circumstances. Compliance is enhanced by a decentralized system in which competition and concern for reputation motivate behavior.

\section{COMMITMENT, COMPLIANCE, AND THE EFFECT OF RULES: FINDINGS}

\section{Why Commit to Article VIII?}

If the reasoning outlined above is correct, then the decision to commit to Article VIII should be strongly influenced by markets that value certainty and policy liberalism. Therefore, the choices of economic competitors should be important factors. Two variables are used here to test this proposition. The first is the proportion of IMF members committed to Article VIII (see the Appendix for all definitions and sources), and the second is the proportion of jurisdictions within a given region that have made such a commitment. The hypothesis is that as the latter proportion increases, so does the likelihood that any given country in that region will make such a commitment.

A serious test requires a battery of economic, institutional, and domestic political controls to minimize the possibility that any regional correlation is spurious. Downs and Rocke (1995) argue persuasively that commitments are endogenous to expectations about future compliance. Because countries with an economy that is vulnerable to sharp swings are likely to find it difficult to comply, susceptibility to balance-of-payments pressure is expected to make a government less likely to accept Article VIII obligations in the first place. Developmental level and the direction of the business cycle also may influence the decision to make a legal commitment with respect to economic policy. Therefore, the following analysis controls for gold and foreign exchange reserves as a proportion of GDP (Reserves/GDP), volatility in this proportion (Reserve Volatility), GDP per Capita, and GDP Growth.
A second set of controls addresses the institutional context. Two of these relate to the IMF's potential role. First, the fund may have policy leverage through the distribution of its resources. If it applies leverage to commit to liberalization, then the use of IMF credits should be associated with a greater propensity to commit to Article VIII. Second, the fund changed its surveillance policy in 1977 in ways that may affect the decision to commit. Previously, governments willing to announce acceptance of Article VIII obligations could avoid multilateral surveillance (Gold 1983; 474-5). ${ }^{6}$ Article XIV countries, in contrast, were subject to wide-ranging and even invasive "consultations," during which the IMF staff broadly reviewed and the Executive Board passed judgment on the member's balanceof-payments position. Therefore, the acceptance rate should be higher, ceteris paribus, before 1977 than after. The third control in this set relates to the varying degree of flexibility in exchange rates among countries. Flexible rates absorb some of the balance-of-payments adjustment burden and mitigate the need for large reserves to defend the currency. At any given reserve level, greater exchange rate flexibility should be associated with a higher propensity to commit.

Domestic political conditions are another likely influence on the decision to commit to Article VIII. Most obviously, a government may choose liberal policies because that is what the polity demands. Article VIII provides a right of access to foreign exchange for residents and nonresidents, which is a valuable guarantee to the traded goods sector. For importers, it signals to foreign firms that the government is not likely to interfere in the foreign exchange market or to intervene arbitrarily in international business transactions. ${ }^{7}$ This provision is also likely to be favored by export groups, who are concerned with issues of reciprocity and retaliation (Gilligan 1997). Trade dependence should positively influence the legal commitment to free and open foreign exchange markets. Finally, one might 'expect that civil society's demand for guaranteed foreign exchange access is most likely to be addressed by a democratic regime. In political terms, private interests are likely to oppose the state, which stands to garner concentrated rents as the dispenser of limited access to hard currency. If so, then democratic governance should contribute to a higher rate of Article VIII acceptance.

Before proceeding, a graphic presentation of the data is useful. Figure 1 shows that membership in the IMF has grown considerably over the past three decades, as has the proportion of countries committed to Article VIII. By 1995 a clear majority of members had abandoned transitional status and obligated themselves to openness.

\footnotetext{
${ }^{6}$ Consultations with Article VIII countries were established in 1960 but were completely voluntary (de Vries and Horsefield 1969, 246-7).

7 According to de Vries and Horsefield $(1969,285-6)$, for example, "Article VIII status had come to signify over the years either that a country had a sound international balance of payments position, or that if its payments position was threatened, it would avoid the use of exchange restrictions."
} 


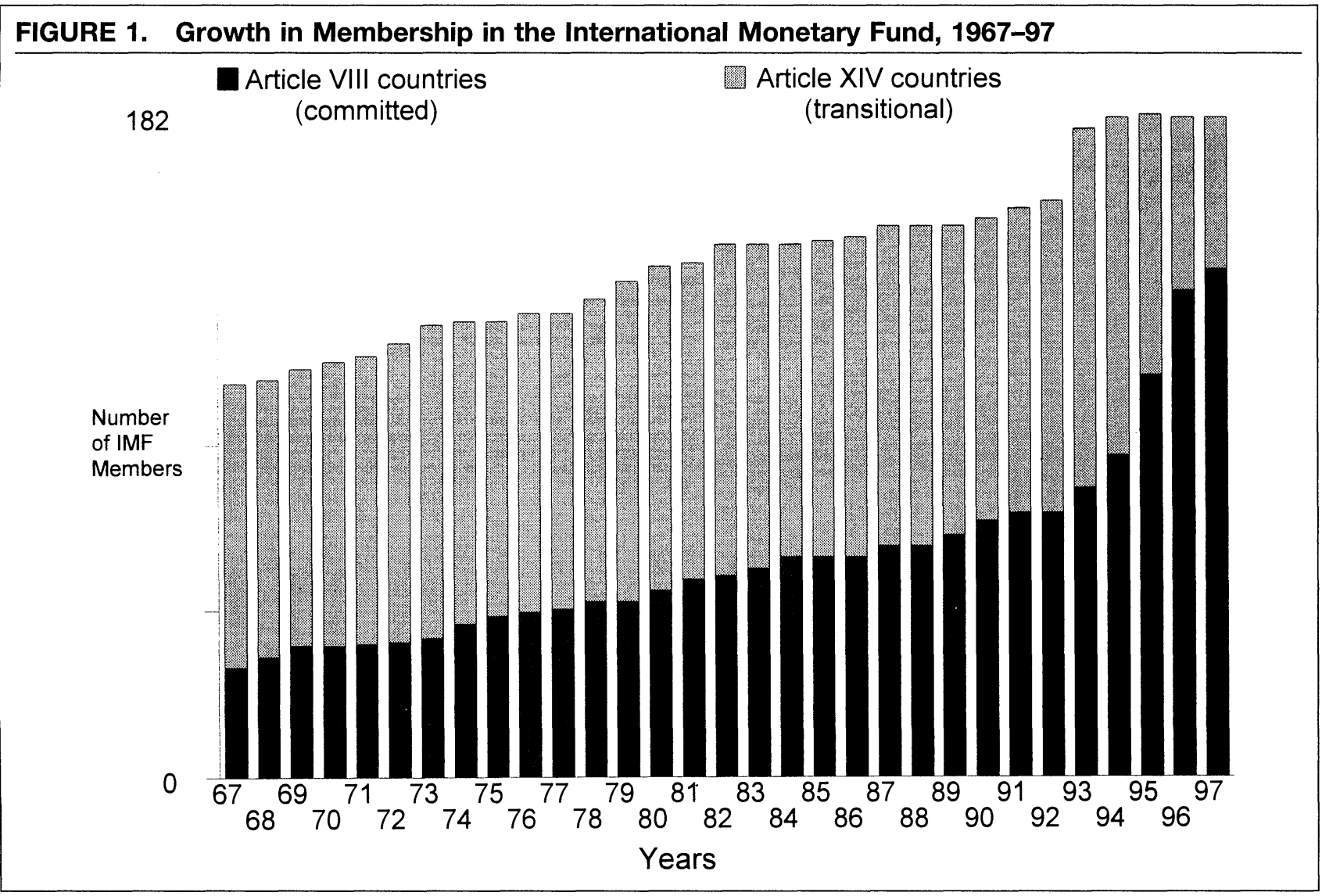

For many countries, the transitional period was lengthy, as indicated by the Kaplan-Meier "survival function" in Figure 2, which uses yearly observations for 153 countries who were members by $1995 . .^{8}$ The Kaplan-Meier function estimates about a $25 \%$ chance of accepting Article VIII status in the first five years of IMF membership, a 50\% chance within 31 years, and about a $75 \%$ chance after 40 years. Clearly, many countries have not rushed to make a legal commitment to keep the current account free from restrictions.

What factors affect the rate of acceptance of the obligations under Article VIII? Note that this is a unidirectional decision: Once made, it cannot be rescinded, although a country can fail to comply with its commitment (discussed below). I use techniques of survival analysis that focus on the spell of time until the event of interest occurs (in this case, an Article VIII commitment). A hazard model is appropriate in this case because it captures the accumulation of "risks" over time that affect the decision to commit. ${ }^{9}$ Specifically, I employ a Cox proportional hazard model to

\footnotetext{
${ }^{8}$ The literature usually terms the event of interest a "failure" and the time elapsed until its occurrence as "survival," regardless of the substantive problem modeled. Proponents of international openness and free markets would view "survival" analysis as "transition" analysis and an Article VIII commitment as a "success"; those who favor closer government management of markets might consider the customary appellations more apt.

9 The hazard model is more general than a panel probit because it allows the underlying probability of committing to Article VIII to change each year. In addition, the structure of the data (all $0 \mathrm{~s}$ and a single switch to 1 at the point of each country's commitment) is
}

examine the effects of a number of continuous and categorical predictors; because some of these vary over time, the tests presented here use time-varying covariates. The Cox model estimates a "hazard rate" for Article VIII acceptance at a particular moment, ${ }^{10}$ and this hazard rate is modeled as a function of the baseline hazard (ho) at time $t$, which is simply the hazard for an observation with all explanatory variables set to zero, ${ }^{11}$ as well as a number of explanatory variables, the estimates of which indicate proportional changes relative to this baseline hazard.

Table 1 presents the findings of the Cox proportional hazard estimation for the variables discussed above. (Note that a ratio of more than 1 indicates an increase in the rate of Article VIII acceptance, and a ratio of less than 1 indicates a reduction in the rate of acceptance.) Model 1 is a reduced form version that includes only relevant variables for which a very strong case can be made that they are exogenous to the commitment decision. Models 2-4 present the effects of variables that are arguably endogenous to some degree, as well as other exogenous variables for which one cannot reject the null hypothesis of no effect on the baseline

analogous to "death" in the epidemiological studies in which such models are frequently employed.

10 The hazard rate is defined as:

$h(t)=\frac{\text { probability of accepting Art. VIII between times } t \text { and } t+1}{\text { (probability of accepting Art. VIII after time } t \text { ) }}$.

11 In this case, I have set all variables to their minimum value in order to avoid interpretations based on deviations from unobserved values of the explanatory variables. 


\section{FIGURE 2. The Kaplan-Meier Survival Function Duration of Article XIV Status over Time}

$$
\text { Kaplan-Meier survival estimate }
$$

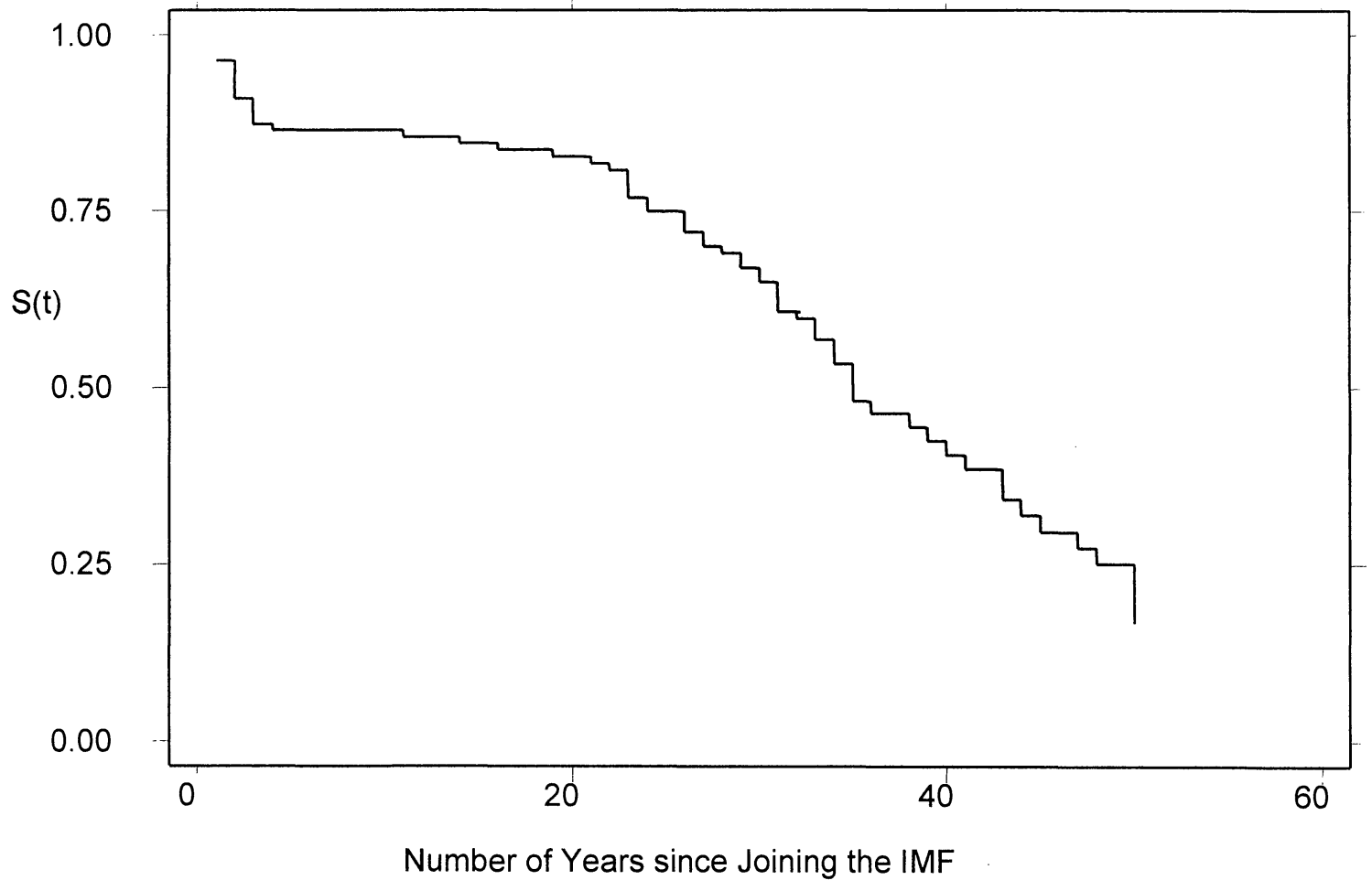

hazard rate. Data availability causes the sample size to change somewhat, but none of the conclusions discussed below are altered substantially by analyzing a common sample.

The first two variables, Universality and Regional Norm, test the proposition that taking on an obligation is likely to be related to similar actions by others. Both of these have a large and positive influence on the acceptance rate. According to model 2, for example, every increase of one percentage point in the proportion of IMF members who accept Article VIII increases by $5.5 \%$ the likelihood of acceptance by other members. A similar increase in the regional proportion of Article VIII adherents increases a country's likelihood of acceptance by $2.7 \%$. This translates into an increase of $31 \%$ in the rate of acceptance for every increase of $10 \%$ in regional accession. ${ }^{12}$ Clearly, as the number of countries who adhere to Article VIII increases, there is a much greater chance that an uncommitted government will do so. Note that this effect is significant even when controlling for time (Year in model 4), which reduces the likelihood that the universality and regional norms variables simply reflect an increase in adherents over time.

There is also evidence that institutional incentives make some difference in Article VIII acceptance. Surveillance (a dummy variable with the value of 0 before 1977, 1 thereafter) has the expected negative

12 This is calculated by raising the estimated hazard ratio to the tenth power. effect, although it is not robustly statistically significant for this sample of countries, many of which joined the IMF after surveillance became mandatory for all members. ${ }^{13}$ Moreover, the coefficient is significantly weakened by including year as an explanatory variable. This is understandable, since surveillance is a dichotomous dummy that distinguishes years before and after 1977. Flexible exchange. rates probably increase the likelihood of making an Article VIII commitment, since these minimize the foreign exchange reserves needed to defend a beleaguered currency, but the statistical significance varies with the model specification.

Perhaps most interesting is the fairly strong and consistent negative effect of the use of fund credits on the Article VIII decision. This provides evidence that the IMF is not effectively using resources as leverage to pressure borrowers into making a legal commitment. ${ }^{14}$ In fact, Use of Fund Credits reduces the proportional

\footnotetext{
${ }^{13}$ For countries that had joined the IMF by 1980 , earlier research shows that the change in the surveillance regime had a very strong negative effect on the decision to commit to Article VIII, which indicates a rather perverse incentive to commit. Mandatory surveillance for all countries drastically reduced the probability of accepting Article VIII by countries that were members during the regime change (Simmons 2000).

${ }^{14}$ This finding is consistent with archival research, which suggests that the IMF is more likely to recommend that a country delay commitment to Article VIII when its balance of payments is under pressure (Simmons 2000). The reason is that such a commitment not only would lack credibility but also would allow the "leakage" of IMF resources to pay private creditors rather than to buy time for the government to make fundamental economic policy adjustments.
} 


\begin{tabular}{|c|c|c|c|c|}
\hline Explanatory Variable & Reduced form Model 1 & Model 2 & Model 3 & Model 4 \\
\hline Universality & $\begin{array}{l}.066^{*} \\
(.010)\end{array}$ & $\begin{array}{l}1.055^{\star} \\
(.011)\end{array}$ & $\begin{array}{c}1.247^{*} \\
(.089)\end{array}$ & $\begin{array}{l}1.040 \\
(.024)\end{array}$ \\
\hline Regional Norm & $\begin{array}{c}1.029^{*} \\
(.005)\end{array}$ & $\begin{array}{c}1.027^{*} \\
(.005)\end{array}$ & $\begin{array}{l}1.038^{\star} \\
(.010)\end{array}$ & $\begin{array}{c}1.028^{\star} \\
(.005)\end{array}$ \\
\hline Use of Fund Credits & - & $\begin{array}{l}.534^{*} \\
(.160)\end{array}$ & $\begin{array}{l}.577^{\star} \\
(.241)\end{array}$ & $\begin{array}{l}.548^{\star} \\
(.169)\end{array}$ \\
\hline Flexible Exchange Rate & - & $\begin{array}{l}1.52 \\
(.418)\end{array}$ & $\begin{array}{c}2.659^{*} \\
(1.286)\end{array}$ & $\begin{array}{l}1.512 \\
(.409)\end{array}$ \\
\hline Surveillance & - & - & $\begin{array}{l}0.46^{*} \\
(.053)\end{array}$ & $\begin{array}{l}.407 \\
(.295)\end{array}$ \\
\hline Openness (Trade Dependence) & $\begin{array}{c}1.008^{*} \\
(.002)\end{array}$ & $\begin{array}{c}1.009^{*} \\
(.003)\end{array}$ & $\begin{array}{r}1.019^{\star} \\
(.004)\end{array}$ & $\begin{array}{l}1.009^{*} \\
(.179)\end{array}$ \\
\hline Democracy & - & - & $\begin{array}{l}1.028 \\
(.034)\end{array}$ & - \\
\hline GNP/Capita & $\begin{array}{c}1.00007^{\star} \\
(.00002)\end{array}$ & $\begin{array}{c}1.00007^{\star} \\
(.00003)\end{array}$ & $\begin{array}{c}1.00009^{\star} \\
(.00004)\end{array}$ & $\begin{array}{c}1.00007 \\
(.00003)\end{array}$ \\
\hline GDP Growth & $\begin{array}{l}1.033 \\
(.020)\end{array}$ & $\begin{array}{l}1.035 \\
(.021)\end{array}$ & $\begin{array}{l}1.021 \\
(.041)\end{array}$ & $\begin{array}{c}1.036 \\
(.022)\end{array}$ \\
\hline Reserves/GDP & - & $\begin{array}{c}1.740 \\
(.493)\end{array}$ & $\begin{array}{c}.950 \\
(1.192)\end{array}$ & $\begin{array}{l}1.744 \\
(.505)\end{array}$ \\
\hline Reserve Volatility & - & $\begin{array}{c}.770 \\
(.157)\end{array}$ & $\begin{array}{l}.883 \\
(.300)\end{array}$ & $\begin{array}{l}.753 \\
(.155)\end{array}$ \\
\hline Year & - & - & 一 & $\begin{array}{l}1.052 \\
(.051)\end{array}$ \\
\hline No. of countries & 133 & 128 & 106 & 128 \\
\hline No. of acceptances & 77 & 72 & 36 & 72 \\
\hline Time "at risk" & $2,462.99$ & $2,375.95$ & $2,177.96$ & $2,375.95$ \\
\hline Log-likelihood & -228.089 & -200.354 & -88.305 & -199.51 \\
\hline$\chi^{2}$ & 163.58 & 165.36 & 80.20 & 163.61 \\
\hline$p>\chi^{2}$ & 0.00 & 0.00 & 0.00 & 0.00 \\
\hline
\end{tabular}

hazard rate by about $44 \%$ (model 1), which is consistent with an argument that links fund assistance with problems of moral hazard. This result makes sense in light of the signaling literature, which suggests that contingent aid makes it much more difficult for a government to signal its true intent about future policy to the market (Rodrik 1989). Because such a signal would be difficult to interpret, there is little reason for a borrowing government to send it.

Domestic political demands that flow from trade openness also have an important influence on the acceptance rate. Openness to the international trade system raises the proportional hazard rate significantly. According to model 1, every increase of one point in imports plus exports as a proportion of GDP increases by $.8 \%$ the likelihood of Article VIII acceptance. This can account for a difference of $26 \%$ in acceptance probability for countries with trade profiles as different as, say, Malaysia (where imports plus exports approxi- mate $80 \%$ of GDP for the period under consideration) and the Philippines (where the corresponding ratio is a little more than 50\%). ${ }^{15}$ The presence of a democratic regime has no independent effect on the propensity to commit to openness (model 3).

Finally, the economic controls basically fulfill expectations, although most fall short of traditional standards of statistical significance. A commitment to external liberalization is more likely under good and improving economic conditions. High per-capita income, high GDP growth, and strong reserves of foreign exchange are likely to influence a government to commit (the latter two with a probability of $<.10$ ). Reserve volatility, although not statistically significant at traditional levels, is correctly signed. ${ }^{16}$ What is

\footnotetext{
15 This is calculated by raising the estimated hazard ratio to the 29 th power.

${ }^{16}$ Current account balance and volatility as well as terms of trade
} 
TABLE 2. Rates and Years of Noncompliance Due to Restrictions on Current Account, by Country, 1967-97

\begin{tabular}{|c|c|c|c|}
\hline Country & $\begin{array}{c}\text { Rate of Noncompliance } \\
(1967-97)\end{array}$ & $\begin{array}{c}\text { Years Committed } \\
(1967-97)\end{array}$ & Dates of Restrictions \\
\hline Dominican Republic & 1.00 & 31 & $1967-97$ \\
\hline El Salvador & .87 & 31 & 1967-93 \\
\hline Jamaica & .81 & 31 & 1968-69, 1973-95 \\
\hline Guyana & .77 & 31 & $1967,1971-93$ \\
\hline Chile & .75 & 20 & $1983-95,1996-97$ \\
\hline South Africa & .71 & 24 & $1979-93,1996-97$ \\
\hline Cyprus & .71 & 7 & $1991-93,1996-97$ \\
\hline Iceland & .64 & 14 & 1984-92 \\
\hline Morocco & .60 & 5 & $1993,1996-97$ \\
\hline Argentina & .59 & 29 & $1972-77,1983-93$ \\
\hline Costa Rica & .55 & 31 & $1972-73,1975,1982-95$ \\
\hline Peru & .55 & 31 & $1971-78,1985-92,1996$ \\
\hline St. Lucia & .53 & 15 & $1981-86,1996-97$ \\
\hline Guatemala & .52 & 31 & $1967-73,1981-89$ \\
\hline St. Vincent & .50 & 14 & $1982-86,1996-97$ \\
\hline Barbados & .50 & 4 & 1996-97 \\
\hline Israel & .50 & 4 & 1996-97 \\
\hline Nicaragua & .48 & 31 & 1979-93 \\
\hline Ecuador & .41 & 27 & 1983-93 \\
\hline Greece & .40 & 5 & 1996-97 \\
\hline Tunisia & .40 & 5 & 1996-97 \\
\hline Honduras & .39 & 31 & $1982-93$ \\
\hline Fiji & .28 & 25 & $1989-92,1996-97$ \\
\hline Italy & .26 & 31 & $1975-82$ \\
\hline Swaziland & .25 & 8 & 1996-97 \\
\hline Turkey & .25 & 8 & $1996-97$ \\
\hline Grenada & .25 & 4 & 1997 \\
\hline Austria & .23 & 31 & $1967-73$ \\
\hline Bolivia & .23 & 30 & $1982-86,1996-97$ \\
\hline Korea & .22 & 9 & 1996-97 \\
\hline Belize & .21 & 14 & $1982,1996-97$ \\
\hline St. Kitts and Nevis & .18 & 11 & 1996-97 \\
\hline Mexico & .16 & 31 & $1983-87$ \\
\hline United Kingdom & .16 & 31 & $1967-71$ \\
\hline Antigua and Barbuda & .14 & 14 & 1996-97 \\
\hline France & .13 & 31 & 1969-71, 1983 \\
\hline Haiti & .13 & 31 & $1968-71$ \\
\hline Dominica & .11 & 18 & 1996-97 \\
\hline Japan & .10 & 30 & $1968-70$ \\
\hline Oman & .09 & 23 & 1996-97 \\
\hline Papua New Guinea & .09 & 22 & 1996-97 \\
\hline Bahamas & .08 & 24 & $1996-97$ \\
\hline Netherlands Antilles & .06 & 31 & 1996-97 \\
\hline Solomon Islands & .06 & 18 & 1997 \\
\hline Singapore & .05 & 21 & 1997 \\
\hline
\end{tabular}




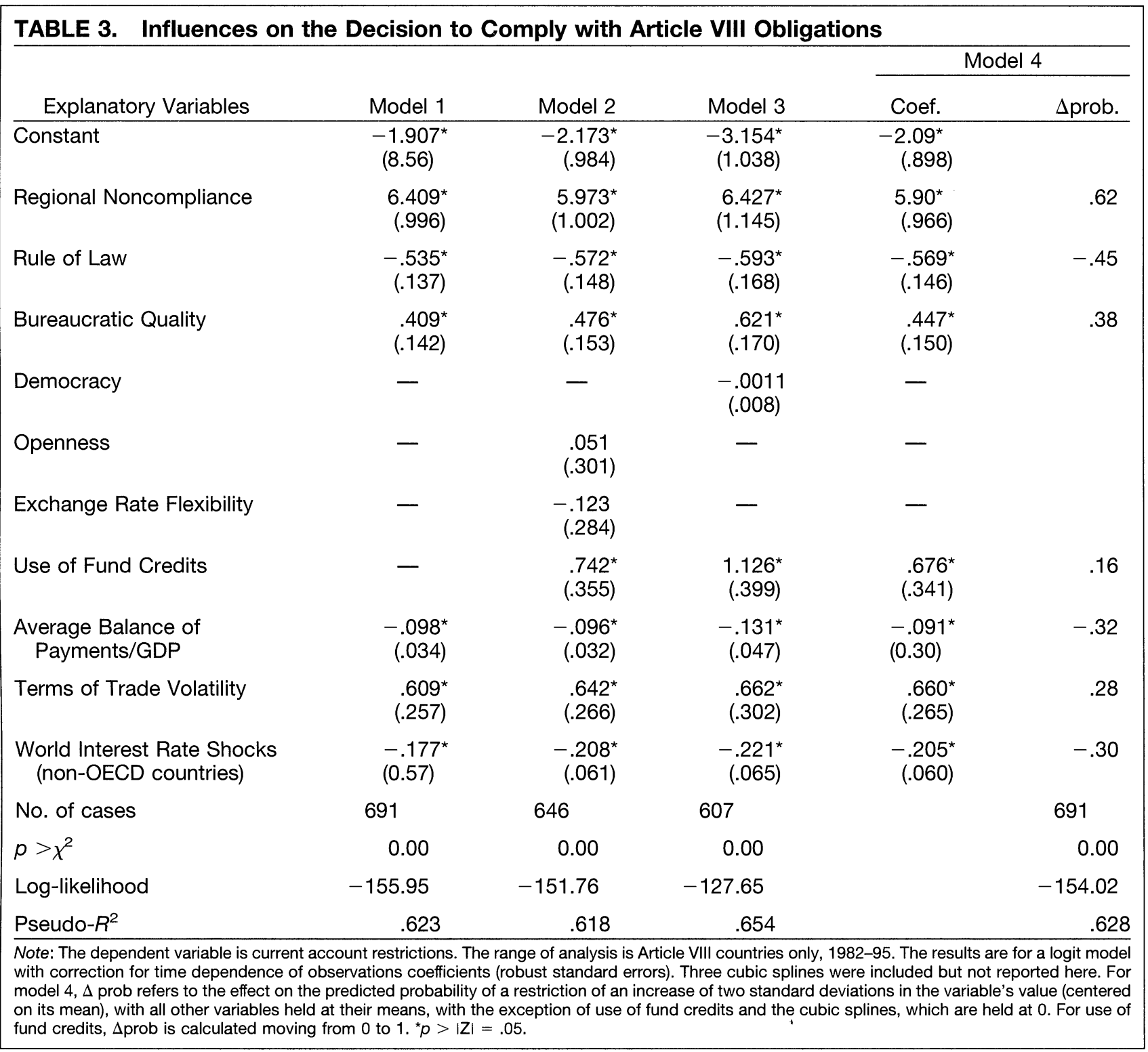

interesting is the apparent strength of external behavior as an influence on the commitment decision, even when controlling for economic conditions to which governments obviously feel pressures to respond. This seems to suggest that "peer pressure" in a competitive market context, rather than either IMF pressure or economic conditions alone, are in part driving the willingness of governments to make a legal commitment to a liberal international monetary policy.

\section{Why Comply with an Article VIII Commitment?}

Members of the IMF are legally required to fulfill their commitment to keep the current account free from restrictions and to maintain unified exchange rates. Although 38 members have a perfect record on both

volatility were also analyzed. The results were insignificant and are not reported here. counts, ${ }^{17}$ the same cannot be said for the countries listed in Table 2. Most of the long-term noncompliers are concentrated in Latin America, despite the marked trend toward liberalization in this region during the mid-to-late 1990s. The global financial crisis of 1996-97 elicited foreign exchange restrictions in a number of Article VIII countries that otherwise had exemplary records (e.g., Singapore and Korea).

What explains the variance in compliance among countries that have chosen openness? This section focuses only on cases in which governments have

17 As of 1997: Armenia, Bahrain, Canada, Denmark, Djibouti, Estonia, Finland, Gambia, Germany, Hungary, Indonesia, Kiribati, Kyrgyz Republic, Latvia, Lebanon, Malaysia, Marshall Islands, Mauritius, Micronesia, Mongolia, New Zealand, Norway, Panama, Portugal, Qatar, Russia, San Marino, Saudi Arabia, Seychelles, Spain, Sweden, Switzerland, Thailand, Trinidad and Tobago, United Arab Emirates, United States, Vanuatu, and Yemen Arab Republic. There are very few yearly observations on several of these cases, however. 
committed to Article VIII and then implemented restrictions on the current account. ${ }^{18}$ The most obvious explanation is economic pressure that makes the maintenance of an open current account and unified exchange rates very difficult. Certainly, that is a likely factor in Latin America in the 1980s and in Asian countries in recent years. In the tests that follow I present results that control for Average Balance of Payments/GDP, Terms of Trade Volatility, and World Interest Rate Shocks. These are chosen not only because they can have a substantial effect on the ability of governments to maintain a current account free of restrictions, but also because they are unmistakably exogenous to a government's policy at any particular time.

My central concern is the pressure that the behavior of other similarly situated countries places on the decision to comply. Investors and suppliers should prefer to do business in countries whose legal framework protects international contracts. In Table 3, Regional Noncompliance reflects the extent to which countries within the same region have implemented restrictions on current accounts. On the one hand, the expectation is that if Article VIII countries in the region often disregarded their commitment, then the probability increases that any given country in that area will not comply. On the other hand, the more competitors are willing to comply, the greater is the pressure for any one country to comply, even in the face of conditions that favor protecting the national economy through restrictions.

The institutional context also may be important for the compliance question. First, if the IMF is "enforcing" liberal legal obligations through the conditional distribution of resources, then one would expect the use of these credits to be associated at the margin (i.e., controlling for economic conditions) with compliance. Second, compliance may be more palatable if it is not essential to maintain reserves to defend a fixed value of the currency. Flexible rates should be associated with greater compliance.

Finally, it is important to consider characteristics of the domestic polity itself. Several authors imply that compliance with international legal commitments is much more prevalent among liberal democracies, due to the constraining influence exercised by domestic groups with an interest in or a preference for compliant behavior (Schachter 1991, 7; Young 1979; see also Moravcsik 1997). In this view participatory politics may pressure the government, especially if noncompliance curtails the rights of residents to foreign exchange. Others argue that the most important characteristic of liberal democracy in terms of international compliance is a strong domestic commitment to the rule of law. The many variants of this argument range from that of Slaughter (1995), who maintains that independent judiciaries in liberal democracies seem to share some of

\footnotetext{
18 This is presented as a priori evidence of noncompliance, even though at this point I do not examine the technical question as to whether the IMF Executive Board approved the restrictions in place, rendering them "legal" temporarily.
}

the same substantive approaches to law, to a more general contention that domestic systems that value rule-based decision making and dispute resolution are also more likely to respect rules internationally. ${ }^{19}$ In essence, these are affinity arguments: Domestic norms regarding limited government, respect for judicial processes, and regard for constitutional constraints "carry over" into the realm of international politics. ${ }^{20}$ They rest on an intuitively appealing assumption that policymakers and lawmakers are not able to park their normative perspectives at the water's edge (RisseKappen 1995).

There are other reasons to expect the rule of law to be associated with Article VIII compliance. Rule-oflaw countries have a strong positive reputation for maintaining a stable framework for property rights. Markets expect them to keep their commitments, and to undermine this expectation would prove costly. Countries that score low with respect to the rule of law do not have much to lose by noncompliance; erratic behavior is hardly surprising to investors and traders. I use an indicator that is especially appropriate to test the market's assessment of the reputation for rule of law: a six-point scale published by a political risk analysis firm expressly to assess the security of investments (see Knack and Keefer 1995, 225). The scale measures the willingness of citizens peacefully to implement law and adjudicate disputes using established institutions. Higher scores indicate such institutional characteristics as a strong court system, sound political institutions, and provisions for orderly succession. Low scores reflect extralegal activities in response to conflict and to settle disputes.

Because I have argued that compliance is market enforced and that markets prefer certainty in the legal framework, the comparison between the participatory characteristics of democracy and rule-of-law regimes should be especially telling. There is no reason to expect that democracy alone provides the stability that economic agents 'desire; on the contrary, popular participation along with weak guarantees for fair enforcement of property rights can endanger these rights. It is true that the two variables are positively correlated $($ Pearson $=.265)$, but they are certainly conceptually distinct and may have very different effects on the decision to comply with Article VIII. In particular, I directly compare two regime characteristics that are often conflated: the participatory dimensions of $D e$ mocracy and the procedural emphasis of the rule of law. A measure for Bureaucratic Competence is also included to control for the differential capacity of states to intervene in foreign exchange markets.

In this case the compliance decision is modeled using a logistical regression (logit) model; the dependent

\footnotetext{
19 This captures the flavor of some of the democratic peace literature, such as Doyle (1986), Dixon (1993), and Raymond (1994). 20 "International law is not unlike constitutional law in that it imposes legal obligations upon a government that in theory the government is not free to ignore or change" (Fisher 1981, 30). Constitutional constraints most often rest on their shared normative acceptance rather than on the certainty of their physical enforcement, which is another possible parallel to the international setting.
} 
variable has a value of 1 for the presence of restrictions, 0 for their absence. (Since I am analyzing only Article VIII countries, restrictions constitute noncompliance.) Because the data consist of observations across countries and over time, with a strong probability of temporal dependence among observations, a logit specification is used that takes explicit account of the nonindependence of observations (Beck, Katz, and Tucker 1998). ${ }^{21}$ The results are reported in Table 3.

One of the most important findings is, again, the clustering of compliance behavior across regions. Article VIII countries are much more likely to put illegal restrictions on current accounts if other countries in the region are doing so. Can this be due to common economic pressures in the region? That possibility cannot be ruled out completely, but it is rendered less likely by the range of economic variables included in the specification. Various measures of the current account, trade volatility, and interest rate shocks failed to wash out apparent regional mimickry. Three other economic variables (GNP per capita, change in GDP, and reserves as a proportion of GDP) were included in the analysis but are not reported here, since they were not statistically significant and did not affect the results reported above. Compliance decisions are apparently not being made on the basis of economic conditions alone but with an eye to standards of regional behavior. The most obvious reason would be reputational consequences in a competitive international economy. Indeed, one possible indication of the importance of reputational pressures may be found in the influence of world interest rates. As these increase (indicating a more competitive global environment for capital), nonOECD governments were much less likely, ceteris paribus, to violate Article VIII commitments, despite the fact that higher rates are likely to increase balanceof-payments pressures.

The domestic political variables tell an interesting story with respect to regime characteristics. First, the evidence is strong that states must have the bureaucratic capacity to renege on their commitments. The strong positive relationship between bureaucratic quality and restrictions implies that these choices are more likely to be made when the capacity exists to implement them. Second, trade dependence has virtually no effect on these results. Third, in contrast with theories of international behavior that concentrate on the law-consciousness of democracies, the evidence here suggests that democracy contributes little or nothing when other factors are held constant, 22 but a strong domestic com-

\footnotetext{
${ }^{21}$ This solution takes advantage of the fact that annual time-series cross-sectional data with a dichotomous dependent variable are equivalent to grouped duration data. To take explicit account of the temporal grouping of the dependent variable, a counter vector was created, such that $t=0$ if a restriction is in place or if a country is in the first year of current account liberalization. Successive years of no restrictions are coded $1,2, \ldots, n$ for each year beyond year one. Three cubic splines were then calculated based on this count according to a routine made available on Richard Tucker's website (http: // www.fas.harvard.edu/ rtucker/papers/grouped/grouped3. html). The cubic splines were included as explanatory variables, but their coefficients are not reported here. The splines are important as a corrective for assuming that observations are time-independent in this time-series cross-sectional logit framework.

22 For a subset of countries that were IMF members by 1980 , earlier
}

mitment to the rule of law contributes positively to compliance. In fact, a move from one standard deviation below to one standard deviation above the mean on the rule-of-law scale (from 2.3 to 5.7 on the six-point scale) reduces the probability of noncompliance by .45 , according to model 4 , holding other variables constant.

If the IMF enforced compliance, we might expect borrowing from the fund to have a strong negative effect on the dependent variable. Yet, the coefficient is positive and statistically significant. The fund is tolerating a good deal of noncompliance when it comes to restricting access to foreign exchange, ${ }^{23} \mathrm{a}$ finding that is inconsistent with the successful use of leverage.

\section{To Commit or Not to Commit: What Is the Difference?}

I now consider whether the law matters. Specifically, does an Article VIII commitment have an independent effect on behavior, once we take into account the obvious economic factors that are likely to lead to restrictions?

In order to answer this question, I examine the entire data set (133 countries, including Article VIII and Article XIV cases, with observations over time averaging 20 years) using logit analysis to explain the existence of restrictions. ${ }^{24}$ Article VIII commitment is forced to compete with a broad range of economic conditions that clearly are associated with restrictions: volatility in the terms of trade, reserves, and the balance of payments; poor economic growth rates; and low GNP per capita. ${ }^{25}$

Table 4 presents the results of this analysis. Most of the economic variables have the expected effects, and many are significant. Strong influences are associated with terms of trade volatility and business cycles (both clearly exogenous to the decision to restrict current accounts), balance-of-payment difficulties (reasonably exogenous), and low reserves. But because reserves may be endogenous to the decision to restrict the current account, they are not included in model 1 , the reduced form exogenous version. As seen in earlier analysis of the Article VIII countries alone, trade openness is al-

research shows a negative correlation between democracy and compliance with respect to restrictions on current accounts (Simmons 2000).

23 This is completely consistent with archival research, which has uncovered evidence that stand-by arrangements are often accompanied by the temporary approval of restrictions in order to conserve foreign exchange.

${ }^{24}$ The same technique for time-dependence of observations is used as described above.

25 The previous analysis suggests that Article VIII status itself is endogenous, but this endogeneity is not taken into consideration here. First, it is not obvious how to go about creating an instrument for Article VIII, given the structure of the data and the events analysis in the first phase of the argument. Second, a case can be made that one should avoid instruments in cases in which the instrument does not correlate very strongly with the endogenous variable (Bound, Jaeger, and Baker 1995). Third, an anonymous reviewer suggests that the observable variables in the compliance model are very likely to control for nonrandom selection into Article VIII status. For a discussion of controlling for selection on observables, see Heckman and Robb 1985, 190-1. 
TABLE 4. Restrictions on Current Account: Does Article VIII Commitment Matter?

\begin{tabular}{|c|c|c|c|c|}
\hline \multirow[b]{2}{*}{ Explanatory Variables } & \multirow[b]{2}{*}{ Model 1} & \multirow[b]{2}{*}{ Model 2} & \multicolumn{2}{|c|}{ Model 3} \\
\hline & & & Coef. & $\Delta$ prob. \\
\hline Constant & $\begin{array}{r}-.699 \\
(.413)\end{array}$ & $\begin{array}{l}.680^{*} \\
(.331)\end{array}$ & $\begin{array}{l}.598^{\star} \\
(.355)\end{array}$ & \\
\hline Article VIII Commitment & $\begin{array}{l}-.903^{*} \\
(.136)\end{array}$ & $\begin{array}{c}-1.101^{*} \\
(.135)\end{array}$ & $\begin{array}{r}-1.111^{*} \\
(.130)\end{array}$ & -.18 \\
\hline Regional Restrictions & $\begin{array}{l}4.00^{*} \\
(.395)\end{array}$ & - & - & \\
\hline Terms of Trade Volatility & $\begin{array}{l}.337^{\star} \\
(.099)\end{array}$ & $\begin{array}{l}.417^{\star} \\
(.095)\end{array}$ & $\begin{array}{l}.403^{*} \\
(.094)\end{array}$ & .18 \\
\hline Balance of Payments/GDP & $\begin{array}{r}-.016^{\star} \\
(.008)\end{array}$ & $\begin{array}{l}-.022^{*} \\
(.008)\end{array}$ & $\begin{array}{r}-019^{\star} \\
(.007)\end{array}$ & -.09 \\
\hline GNP/Capita & $\begin{array}{l}.00004 \\
(.00002)\end{array}$ & - & - & \\
\hline Reservers/GDP & - & $\begin{array}{l}1.43^{\star} \\
(.526)\end{array}$ & $\begin{array}{l}.957^{*} \\
(.353)\end{array}$ & .05 \\
\hline Change in GDP & $\begin{array}{r}-.032^{\star} \\
(.013)\end{array}$ & $\begin{array}{r}-.026^{\star} \\
(.012)\end{array}$ & $\begin{array}{r}-.027^{\star} \\
(.011)\end{array}$ & -.14 \\
\hline Openness & $\begin{array}{c}-.002 \\
(.001)\end{array}$ & $\begin{array}{r}-.003 \\
(.002)\end{array}$ & - & \\
\hline Use of Fund Credits & - & $\begin{array}{l}.826^{\star} \\
(.132)\end{array}$ & $\begin{array}{l}.880^{*} \\
(.131)\end{array}$ & .34 \\
\hline Flexible Exchange Rates & - & $\begin{array}{l}.146 \\
(.156)\end{array}$ & - & \\
\hline $\begin{array}{l}\text { Years since Last } \\
\text { Restriction }\end{array}$ & $\begin{array}{r}-1.226^{*} \\
(.108)\end{array}$ & $\begin{array}{r}-1.272^{*} \\
(.111)\end{array}$ & $\begin{array}{r}-1.26^{\star} \\
(.109)\end{array}$ & -.38 \\
\hline No. of cases & 3,053 & 3,060 & 3,100 & \\
\hline$p>x^{2}$ & 0.00 & 0.00 & 0.00 & \\
\hline Log-likelihood & -751.75 & -805.39 & -819.89 & \\
\hline Pseudo- $R^{2}$ & .64 & .62 & .62 & \\
\hline $\begin{array}{l}\text { Note: The results of a time-series cr } \\
\text { standard errors. Three cubic spline } \\
\text { restriction of an increase of two sta } \\
\text { exception of use of fund credits, yee } \\
\text { from } 0 \text { to } 1 \text {. For years since last re }\end{array}$ & $\begin{array}{l}\text { model are report } \\
\text { but not reporte } \\
\text { in the variable's } \\
\text { riction, and the c } \\
\mathrm{s} \text { calculated mov }\end{array}$ & $\begin{array}{l}\text { ndent variable } \mathrm{i} \\
\text { model } 3, \Delta \mathrm{prc} \\
\text { ered on its me } \\
\text { which are held } \\
\text { o } 5 .{ }^{*} p>|\mathrm{Z}|=\end{array}$ & $\begin{array}{l}\text { Irrent accounts; } \\
\text { fect on the pred } \\
\text { ariables held at } \\
\text { ad credits, } \Delta \text { prob }\end{array}$ & $\begin{array}{l}\text { are robust } \\
\text { ability of a } \\
\text { s, with the } \\
\text { ed moving }\end{array}$ \\
\hline
\end{tabular}

so likely to be associated with liberal policy choice, although certainty does not quite reach standard levels of significance $(p<.10)$. Another interesting finding is that use of fund credits is consistently strongly associated with illiberal policy choice, which again provides evidence that these choices cannot convincingly be explained by fund pressure in the context of extending loans.

Most important for my purposes, however, is that controlling for every likely macroeconomic influence on the decision to implement current account restrictions, a formal declaration of adherence to Article VIII obligations consistently has a strong negative effect on the probability of imposing restrictions. In fact, controlling for all other economic variables as well as for policy inertia, ${ }^{26}$ countries that continue to live under

\footnotetext{
${ }^{26}$ Here I report the predicted probabilities as generated by a set of
}

the transitional Article XIV regime have an estimated probability of .87 , according to Table 4 , model 3 , of implementing restrictions; the corresponding probability for an identically situated Article VIII country is only .69. Thus, commitment accounts for a percentage point difference of about 18 in the probability of imposing restrictions on current accounts for the sam-

simulation algorithms developed by King, Tomz, and Wittenberg (1998). These routines have the advantage of producing confidence intervals that take into account the uncertainty surrounding the logit parameters. Conventional methods for calculating probabilities from logit regression assume that the parameter estimates are perfectly estimated and, therefore, do not allow us to report adequately the uncertainty surrounding the probabilities. The simulation algorithms of King, Tomz, and Wittenberg, however, generate a full distribution of parameter estimates that can then be converted to probabilities, a mean can be calculated, and meaningful confidence intervals can be drawn. 


\section{FIGURE 3. The Marginal Effect of an Article VIII Commitment on Current Account Restriction, Various Intervals from Last Restriction}

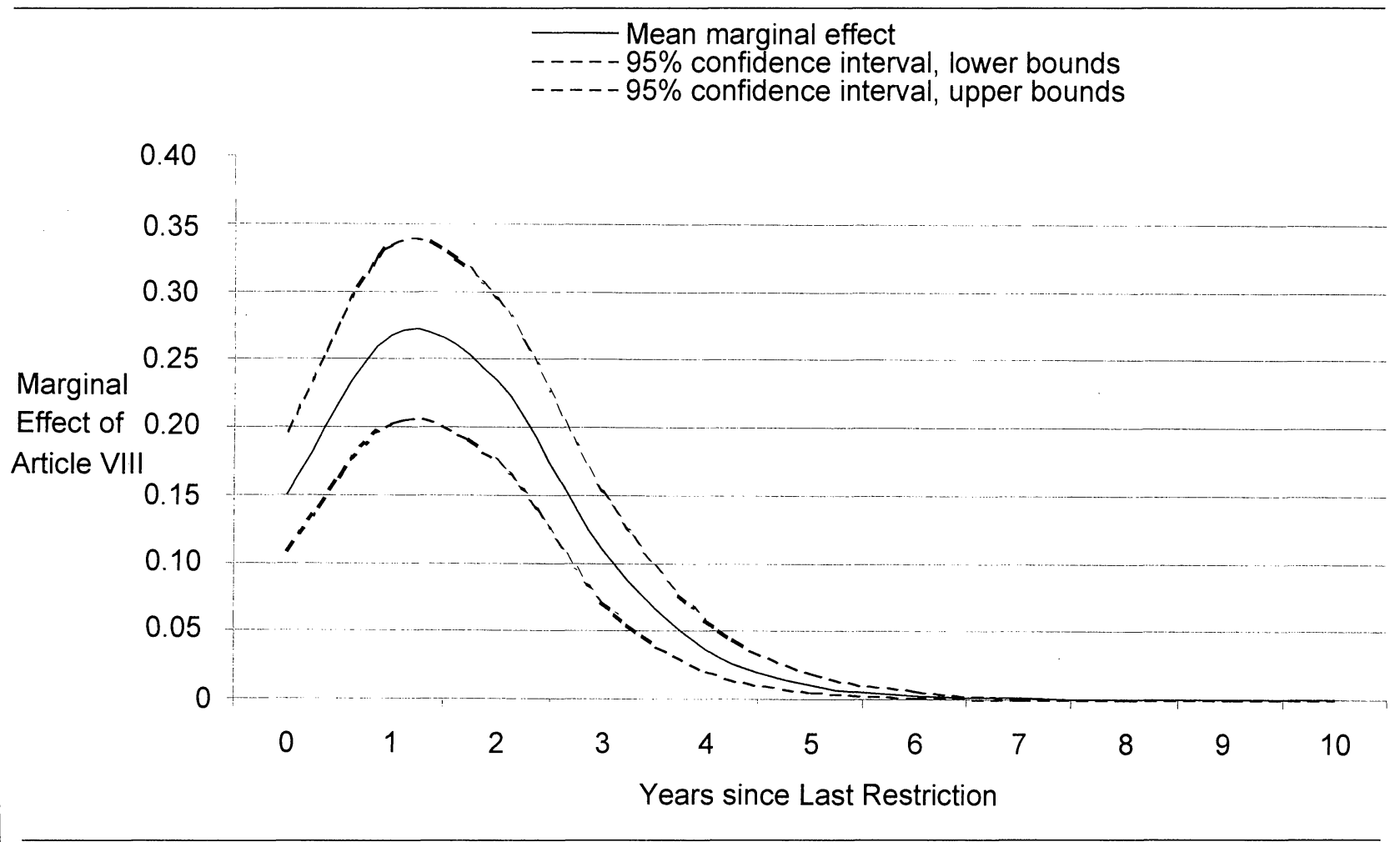

Note: The figure presents simulated effects using results from Table 4, Model 3.

ple of cases as a whole. Even when we control for the policies of other countries in the region, the legal commitment continues to matter greatly (model 1). Clearly, neither economic conditions nor imitative behavior alone can fully account for the decision to eschew restrictions. The legal commitment itself is an important part of the story.

Interestingly, the effect of the legal commitment is distributed unevenly over time. ${ }^{27}$ The marginal effects of commitment reported in Table 4 assumed one year had elapsed since a country's previous restriction. ${ }^{28}$ Figure 3 traces out the marginal effects of commitment on the probability of restrictions as a function of time since the last restrictions. It shows that commitment has the greatest effect in the first two or three years after lifting restrictions. Two years after a restriction, the marginal effect of commitment peaks at about .27, which is a truly significant effect of a legal commitment on behavior. For countries freed from restrictions for the past five years ( 76 cases), the probability of instituting them is .035 with an Article VIII commitment and .058 without, for a

\footnotetext{
27 I have interacted Article VIII with years since last restriction and calendar years and have run analyses in both OLS and logit to see if the results are robust. Nothing changes substantially regarding the importance of making an Article VIII commitment. Additional analysis is available from the author upon request.

28 Denoted as $t=0$ for purposes of the counting vector upon which the cublic splines are calculated (Beck, Katz, and Tucker 1998).
}

marginal effect of about .023 . There is virtually no independent influence on the legal commitment once a country is six years away from its last restriction.

This suggests that the legal commitment is crucial to policy choice in the first few fragile years of liberalization. That is likely to be a period in which the economy is not yet fully stabilized, and the bureaucratic capacity to intervene may still be available. These conditions provide a severe test of the commitment to maintain liberalization. Governments in Article VIII countries need to convince markets that they are serious about coming back into compliance in order to regain lost credibility. Article XIV countries have much less credibility in the first place. In the absence of reputational effects, there is little evidence that they strive as hard to retain any liberalization they are temporarily able to achieve.

It is not at all surprising that this initial effect should deteriorate over time. The longer a country is free from restrictions, the less likely it is to reimplement them. Over time the bureaucratic capacity to intervene is dismantled. Groups advantaged by the policy are likely to adjust their "portfolios" to the liberalized environment as time passes. This is not to say that a shock would not cause relapse; rather, policy inertia is real, and we should expect it to have a marked influence on outcomes. But this only serves to underscore the effects of the international legal commitment to keep current 
accounts free from restrictions. This commitment is a significant factor in whether a liberal inertia has a chance to take hold.

These findings provide fairly strong evidence that legal commitment has a systematic effect on state behavior. It should be underscored that it was shown to affect the propensity to restrict current accounts after controlling for a wide range of economic conditions, the policies of other countries in the region, and the time dependence of observations (policy inertia). It is not easy to counter that these results are merely an endogenous reflection of the actions governments intended to take regardless of a formal commitment. Recall that adherence to Article VIII is a one-way commitment, and in the thirty to fifty years afterward there are certainly likely to be unanticipated occasions on which eschewing restrictions on current accounts proves inconvenient. Nonetheless, in a significant number of such cases, governments apparently decided that their best interests lay in abiding by their commitment to refrain from restrictive policies.

\section{CONCLUSION}

The effect of international law on state behavior should be a central concern of international relations scholarship, but few studies have systematically examined this issue. International legal scholars tend to view law compliance as the norm (Chayes and Chayes 1993; Henkin 1979), but political scientists are far more skeptical (Downs, Rocke, and Barsoom 1996; Mearsheimer 1994-95). In the face of daunting conceptual and methodological issues (Simmons 1998), very little evidence has been accumulated to assess basic propositions about why governments commit to and comply with international legal obligations, and whether this makes any difference to outcomes in which we are interested.

The legalization of some central aspects of the international monetary regime after World War II provides an opportunity to inquire into the conditions under which law can influence the behavior of governments in their choice of international monetary policies. In this issue area, we can be fairly precise about what constitutes obligation and compliance, using the IMF's own data. My strategy has been to model the factors that contribute to the rate of Article VIII acceptance, test a set of propositions regarding compliance with this commitment, and assess the effect of that commitment on behavior.

One of the most interesting findings is that the behavior of other countries, especially in one's own region, has far more influence on commitment and compliance than has generally been recognized. Indeed, there is more evidence of competitive policy convergence than of overt pressure from the IMF on borrowing countries. Especially intriguing is the finding that governments are positively influenced by the choices of others in their region. They are more likely to make and to honor a legal commitment if neighbors are doing so. This provides evidence that norms are set and reputations are assessed among groups of roughly comparable countries, likely through international markets rather than international organizations. Although the IMF undoubtedly has significant influence on some countries at certain times, much more decentralized forces seem largely to be at play.

Among Article VIII countries, two domestic regime effects have clear consequences for compliance. Surprisingly for those who view the international behavior of democracies as somehow distinctive with respect to law and obligation, participatory democracy has little to do with the compliance issue. Regimes based on clear principles of the rule of law are far more likely to comply with their commitments. This indicates that rules and popular pressures can and apparently sometimes do have distinct consequences when it comes to international law compliance. Apparently, governments that provide a stable framework of law and system of property rights domestically are more likely to do the same for international economic transactions. One interpretation is that a credible commitment to a stable system of law is not divisible in the eye of the investor. A rule-of-law government may have even more to lose from noncompliance with an international legal obligation than a more capricious regime.

Perhaps no question has plagued scholars of international institutions as persistently as the challenge to demonstrate that such institutions have a direct effect on state behavior. Does international law order state action? How can we know that governments have not simply committed to do things that they would have done even in the absence of rules? How can we be sure that the rules are not epiphenomenal rather than a constraint on future behavior? "Proof" of such propositions may not be possible, but the evidence presented here addresses such skepticism. Once we control for most of the obvious reasons a government may choose to restrict its current account, Article VIII status still emerges as a truly significant influence on the probability of choosing to restrict. An Article VIII country facing external economic pressures and business cycle conditions matching those of a similarly situated Article XIV country manages much more often to avoid implementing restrictions to cope with these pressures, even if other countries in the region decide to restrict.

This is not simply due to IMF pressure attached to credits, and it is not an artifact of the exchange rate regime. A look at the timing of the estimated effect of commitment reveals something of the law's importance: Significant influence is concentrated in the first few fragile years after a restriction is lifted. Countries that have failed to live up to their obligations seem especially determined to reestablish their credibility. Law seems to matter at a defining moment: Legal commitments can push a country onto a behavioral trajectory of compliance from which it is decreasingly likely to deviate. We should continue to entertain alternative explanations, but these tests indicate that a legal commitment may carry decisive weight in determining some states' international monetary policy.

This article challenges researchers to design projects that will better expose the mechanisms that enhance international law compliance. Does formal commit- 
ment trigger greater external reputational consequences associated with noncompliance than does the same policy in the absence of a commitment? Does a legal commitment have consequences in domestic politics that effectively constrain governmental behavior? Does decentralized "enforcement," whether domestic or international, explain patterns of compliance with other sets of rules to which sovereign governments commit? The answers that eventually emerge will have profound implications for both the theory and practice of international relations.

\section{APPENDIX}

\section{Dependent Variables}

Article VIII Commitment. The variable is scored 1 if a country has accepted Article VIII status, 0 if it remains subject to Article XIV transitional arrangements. Acceptance indicates the end of a "spell" for purposes of the Cox proportional hazard model. Source: IMF various years.

Restriction. Restrictions on payments in current account; scored 1 if restrictions exist; 0 otherwise. When this dependent variable is used only to analyze policies of Article VIII countries, it is interpreted as noncompliance. Source: IMF various years.

\section{Explanatory Variables}

Universality. This refers to the proportion of current IMF members, calculated yearly, who have accepted Article VIII status. Source: IMF various years.

Regional Norm. This refers to the proportion of current IMF members within each region who have accepted Article VIII status. Classification of economies by region (East and southern Africa; West Africa; East Asia and Pacific; Eastern Europe and Central Asia; rest of Europe; Middle East; North Africa; Americas) are based on World Bank categories. Source: IMF various years.

Surveillance. This dummy variable indicates whether the period up to and including (0) or after (1) 1977, when a comprehensive regime of IMF surveillance was instituted for all members, whether Article XIV or Article VIII status.

Use of Fund Credit. The variable is scored 1 if a country has made use of IMF credits during a given year, 0 otherwise. Source: World Bank 1995.

Exchange Rate Flexibility. This variable indicates the extent to which exchange rates are flexible (1) versus fixed (0). If the IMF describes a country's exchange rate as "par value applied" or a "unitary effective ... fixed rate" (1966-73), I code the case fixed; otherwise it is coded flexible. If the IMF describes a country's exchange rate as "not maintained within relatively narrow margins" (1974-82), I code it flexible, otherwise it is coded fixed. If the IMF describes a country's exchange rate regime as a "more flexible arrangement" (1983-98), I code it flexible, otherwise fixed. Source: IMF various years.

Openness. The measure is imports (total value of goods and services: sum of merchandise f.o.b., imports of nonfactor services, and factor payments at market prices in current U.S. dollars) plus exports (total value of goods and services; sum of merchandise f.o.b., exports of nonfactor services, and factor receipts at market prices in current U.S. dollars as a proportion of GDP. Source: World Bank 1995.
Democracy. The score (ranging from a low of 0 to a high of 10) denotes the degree of democratic institutions within each country. Scores are derived from "subjective codings of the competitiveness of political participation, the openness and competitiveness of executive recruitment, and the level of constraints on the chief executive" (Jaggers and Gurr 1995, 411). Source: Jaggers and Gurr 1996.

Balance of Payments/GDP. The measure is the current account balance (the sum of net exports of goods and nonfactor services, net factor income, and net private transfers as a percentage of GPD, before official transfers) as a proportion of GDP for each country for the period under observation. Source: World Bank 1995.

Current Account Volatility. This is the log of the standard deviation of current account balance as a proportion of GDP (defined above). Source: World Bank 1995.

Reserves/GDP. The measure is central monetary authority foreign exchange reserves (including official holdings of gold valued at London market prices, SDR holdings, reserve position at the IMF) in current U.S. dollars as a proportion of GDP. Source: World Bank 1995.

Average Reserves/GDP. The measure is reserves as a proportion of GDP averaged by country for the period under observation.

Reserve Volatility. This is the log of the standard deviation of reserves/GDP. Source: World Bank 1995.

Terms of Trade Volatility. This is the log of the standard deviation of the terms of trade index, which is the relative level of export prices compared with import prices, calculated as the ratio of a country's index of average export price to the average import price $(1987=100)$. Source: World Bank 1995.

World Interest Rate Shock. The measure is U.S. Treasury bill rates, annual average, interacted with non-OECD countries. Source: IMF 1999.

GDP Growth. The GDP average annual growth rate is calculated for the sum of GDP at factor cost and indirect taxes, less subsidies. Source: World Bank 1995.

Regional Noncompliance. This variable is the proportion, calculated yearly, of 'current IMF members within each region who have committed to Article VIII but who place restrictions on current accounts. For classification by region, see regional norms above. This explanatory variable is used only to analyze policies of Article VIII countries, and is interpreted as noncompliance. Source: IMF various years.

Rule of Law. The measure is a six-point scale that determines where a country's domestic polity falls regarding high (6) or low (0) respect for the rule of law. This variable "reflects the degree to which citizens of a country are willing to accept the established institutions to make and implement laws and adjudicate disputes." Higher scores indicate "sound political institutions, a strong court system, and provisions for an orderly succession of power." Lower scores indicate "a tradition of depending on physical force or illegal means to settle claims." Upon changes in government in countries scoring low on this measure, new leaders may be "less likely to accept the obligations of the previous regime" (Knack and Keefer 1995, 225). Source: International Country Risk Guide 2000.

Bureaucratic Quality. A six-point scale measures the extent to which a country's bureaucracy is very capable (6) or incapable $(0)$ of carrying out a range of administrative tasks. For a full discussion of the conceptualization of this variable, 
see Knack and Keefer (1995). Source: International Country Risk Guide 2000.

Years since Last Restriction. A vector was created using the STATA routine made available on Richard Tucker's website (http://www.fas.harvard.edu/ rtucker/papers/grouped/grouped3. html). This is coded 0 if the country restricts or is in the first year of lifting a restriction; otherwise, the years of no restrictions are counted.

\section{REFERENCES}

Abbott, Kenneth, and Duncan Snidal. 2000. "Hard and Soft Law in International Governance." International Organization 54 (Summer): 421-56.

Aman, Alfred C., Jr. 1995. "A Global Perspective on Current Regulatory Reform: Rejection, Relocation, or Reinvention?" Indiana Journal of Global Legal Studies 2 (Spring): 429-64.

Barro, David B., and Robert J. Gordon. 1983. "A Positive Theory of Monetary Policy in a Natural Rate Model." Journal of Political Economy 91 (August): 589-610.

$\rightarrow$ Beck, Nathaniel, Jonathan Katz, and Richard Tucker. 1998. "Taking Time Seriously: Time-Series-Cross-Section Analysis with a Binary Dependent Variable." American Journal of Political Science 42 (October): 1260-88.

Bordo, Michael D., and Finn E. Kydland. 1995. "The Gold Standard as a Rule: An Essay in Exploration." Explorations in Economic History 32 (October): 423-64.

Bordo, Michael D., and Hugh Rockoff. 1996. "The Gold Standard as a 'Good Housekeeping Seal of Approval.' " Journal of Economic History 56 (June): 389-428.

$\rightarrow$ Bound, John, David Jaeger, and Regina Baker. 1995. "Problems with Instrumental Variables Estimation When the Correlation between the Instruments and the Endogenous Explanatory Variable Is Weak." Journal of the American Statistical Association 90 (June): 443-50.

$\rightarrow$ Burley, Anne-Marie Slaughter. 1993. "International Law and International Relations Theory: A Dual Agenda." American Journal of International Law 87 (April): 205-39.

Canzoneri, Matthew B., and Dale W. Henderson. 1991. Monetary Policy in Interdependent Economies. Cambridge, MA: MIT Press.

Cerny, Philip G. 1994. "The Dynamics of Financial Globalization: Technology, Market Structure, and Policy Response." Policy Sciences 27 (November): 319-42.

Chayes, Abram, and Antonia Handler Chayes. 1993. "On Compliance." International Organization 47 (Spring): 175-205.

Chayes, Abram, and Antonia Handler Chayes. 1995. The New Sovereignty: Compliance with International Regulatory Agreements. Cambridge, MA: Harvard University Press.

Cohen, Benjamin J. 1998. The Geography of Money. Ithaca, NY: Cornell University Press.

de Vries, Margaret Garritsen, and J. Keith Horsefield. 1969. The International Monetary Fund, 1945-1965. Vol. II: Analysis. Washington, DC: International Monetary Fund.

Dixon, William J. 1993. "Democracy and the Management of International Conflict." Journal of Conflict Resolution 37 (March): 42-68.

Downs, George, and David M. Rocke. 1995. Optimal Imperfection? Domestic Uncertainty and Institutions in International Relations. Princeton, NJ: Princeton University Press.

Downs, George W., David M. Rocke, and Peter N. Barsoom. 1996. "Is the Good News about Compliance Good News about Cooperation?" International Organization 50 (Summer): 379-406.

Doyle, Michael W. 1986. "Liberalism and World Politics." American Political Science Review 80 (December): 1151-69.

Drazen, Allan. 1997. "Policy Signaling in the Open Economy: A Re-Examination." National Bureau of Economic Research Working Paper No. 5892.

Edwards, Richard W., Jr. 1985. International Monetary Collaboration. Dobbs Ferry, NY: Transnational.

Fisher, Roger. 1981. Improving Compliance with International Law. Charlottesville: University of Virginia Press.

Gilligan, Michael. 1997. Empowering Exporters. Ann Arbor: University of Michigan Press.
Gold, Joseph. 1979. Legal and Institutional Aspects of the International Monetary System: Selected Essays. Washington, DC: International Monetary Fund.

Gold, Joseph. 1983. "Strengthening the Soft International Law of Exchange Arrangements." American Journal of International Law 77 (July): 443-89.

Gold, Joseph. 1988. Exchange Rates in International Law and Organization. Washington, DC: American Bar Association.

Greif, Avner. 1992. "Institutions and International Trade: Lessons from the Commercial Revolution." American Economic Review 82 (May): 128-33. Papers and proceedings of the hundred and fourth annual meeting of the American Economic Association.

Greif, Avner. 1993. "Contract Enforceability and Economic Institutions in Early Trade: The Maghribi Traders' Coalition." American Economic Review 83 (June): 525-48.

$\rightarrow$ Greif, Avner, Paul Milgrom, and Barry R. Weingast. 1994. "Coordination, Commitment, and Enforcement: The Case of the Merchant Guild." Journal of Political Economy 102 (August): 745-76.

Haas, Peter M., Robert O. Keohane, and Marc A. Levy. 1993. Institutions for the Earth: Sources of International Environmental Protection. Cambridge, MA: MIT Press.

Henkin, Louis. 1979. How Nations Behave: Law and Foreign Policy. New York: Council on Foreign Relations.

Heckman, James J., and Richard Robb, Jr. 1985. "Alternative Methods for Evaluating the Impact of Interventions." In Longitudnal Analysis of Labor Market Data, ed. James J. Heckman and Burton Singer. Cambridge: Cambridge University Press. Pp. 156245.

Horsefield, John Keith. 1969. The International Monetary Fund 1945-1965. Volume I: Chronicle. Washington, DC: International Monetary Fund.

Horsefield, John Keith, and Margaret Garritsen de Vries. 1969. The International Monetary Fund, 1945-1965: Twenty Years of International Monetary Cooperation. Washington, DC: International Monetary Fund.

International Country Risk Guide. 2000. Available for purchase at http://prsgroup.com/.crg/icrg.html.

International Monetary Fund (IMF). Various years. Exchange Arrangements and Restrictions. Washington, DC: International Monetary Fund.

International Monetary Fund (IMF). 1999. International Financial Statistics. Washington, DC: International Monetary Fund.

$\rightarrow$ Jaggers, Keith, and Ted Robert Gurr. 1995. “Tracking Democracy's Third Wave with Polity III Data." Journal of Peace Research 32 (4): 469-82.

Jaggers, Keith, and Ted Robert Gurr. 1996. Polity III: Regime Change and Political Authority, 1800-1994 [computer file]. 2d ICPSR version. Boulder, CO: Keith Jaggers/College Park, MD: Ted Robert Gurr [prodúcers], 1995. Ann Arbor, MI: Inter-University Consortium for Political and Social Research [distributor], 1996.

Kegley, Charles W., and Gregory A. Raymond. 1981. "International Legal Norms and the Preservation of Peace, 1820-1964: Some Evidence and Bivariate Relationships." International Interactions 8 (August): 171-87.

$\rightarrow$ Keohane, Robert, and Lisa Martin. 1995. "The Promise of Institutionalist Theory." International Security 20 (Summer): 39-51.

King, Gary, Michael Tomz, and Jason Wittenberg. 1999. "Making the Most of Statistical Analyses: Improving Interpretation and Presentation." http://gking.harvard.edu/preprints.shtml (accessed August 28, 2000).

$\rightarrow$ Knack, Stephen, and Philip Keefer. 1995. "Institutions and Economic Performance: Cross-Country Tests Using Alternative Institutional Measures." Economics and Politics 7 (3): 207-27.

Kydland, Edward C., and Finn E. Prescott. 1977. "Rules Rather than Discretion: The Inconsistency of Optimal Plans." Journal of Political Economy 85 (June): 473-92.

LaPorta, Rafael, Florencio Lopez-De-Silanes, Andrei Shleifer, and Robert W. Vishny. 1997. "Legal Determinants of External Finance." Journal of Finance 52 (July): 1131-50.

Lipson, Charles. 1991. "Why Are Some International Agreements Informal?" International Organization 45 (Autumn): 495-538.

$\rightarrow$ Martin, Lisa L. 1993. "Credibility, Costs, and Institutions: Cooperation on Economic Sanctions." World Politics 45 (April): 406-32.

Maxfield, Sylvia. 1997. Gatekeepers of Growth: The International Political Economy of Central Banking in Developing Countries. Princeton, NJ: Princeton University Press. 
$\rightarrow$ Mearsheimer, John. 1994-95. "The False Promise of International Institutions." International Security 19 (Winter): 5-26.

$\rightarrow$ Milgrom, Paul R., Douglass C. North, and Barry R. Weingast. 1990 "The Role of Institutions in the Revival of Trade: The Law Merchant, Private Judges, and the Champagne Fairs." Economics and Politics 2 (1): 1-23.

$\rightarrow$ Moravcsik, Andrew. 1997. "Taking Preferences Seriously: A Liberal Theory of International Politics." International Organization 51 (Autumn): 513-53.

Oberhansli, Herbert. 1997. "A Global Agreement for Private Investment and Regulatory Competition in Globalizing Markets." Aussenwirtschift 52 (September): 449-71.

Persson, Torsten. 1988. "Credible Macroeconomic Policy: An Introduction and Broad Survey." European Economic Review 32 (March): 519-32.

Persson, Torsten, and Guido Tabellini. 1989. Macroeconomic Policy, Credibility, and Politics. London: Harwood.

Ramcharran, Harri. 1999. "Foreign Direct Investment and Country Risk: Further Empirical Evidence." Global Economic Review 28 (3): 49-59.

Raymond, Gregory A. 1994. "Democracies, Disputes, and ThirdParty Intermediaries." Journal of Conflict Resolution 38 (1): 24-42.

Risse-Kappen, Thomas. 1995. Cooperation among Democracies: The European Influence on U.S. Foreign Policy. Princeton, NJ: Princeton University Press.

$\rightarrow$ Rodrik, Dani. 1989. "Promises, Promises: Credible Policy Reform via Signaling.” Economic Journal 99 (September): 756-72.

Rowlands, Dane. 1993. "Constitutional Rules, Reputation, and Sovereign Debt." Journal of International Economics 35 (November): $335-50$.

Schachter, Oscar. 1991. International Law in Theory and Practice. Dordrecht: Martinus Nijhoff. $\rightarrow$ Simmons, Beth A. 1998. "Compliance with International Agreements." Annual Review of Political Science 1:75-93.

$\rightarrow$ Simmons, Beth A. 2000. "The Legalization of International Monetary Affairs.” International Organization 54 (Summer): 573-602.

Sinn, Hans-Werner. 1999. "The Competition between Competition Rules." National Bureau of Economic Research Working Paper No. W7273.

Slaughter, Anne-Marie. 1995. "International Law in a World of Liberal States." European Journal of International Law 6: 503-38.

Sobel, Andrew C. 1999. State Institutions, Private Incentives, Global Capital. Ann Arbor: University of Michigan Press.

Spence, A. Michael. 1974. Signaling: Information Transfer in Hiring and Related Processes. Cambridge, MA: Harvard University Press.

Staiger, Robert W., and Guido Tabellini. 1987. "Discretionary Trade Policy and Excessive Protection." American Economic Review 77 (December): 823-37.

Tiebout, Charles. 1956. "A Pure Theory of Local Expenditure." Journal of Political Economy 44 (October): 416-24.

$\rightarrow$ Tillema, H. K., and J. R. Van Wingen. 1982. "Law and Power in Military Intervention." International Studies Quarterly 26 (June): 220-50.

Wei, Shang Jin. 2000. "How Taxing Is Corruption on International Investors?" Review of Economics and Statistics 82 (February): $1-11$.

Weiss, Edith Brown, and Harold K. Jacobson, eds. 1998. Engaging Countries: Strengthening Compliance with International Accords. Cambridge, MA: MIT Press.

World Bank. 1995. World Data, CD Rom, STARs Retrieval System. Washington, DC: World Bank.

Young, Oran. 1979. Compliance with Public Authority. Baltimore, MD: Johns Hopkins University Press. 